\title{
The Biology of Botrytis Cinerea Pers. Isolated from Different Geranium Varieties
}

\author{
Raluca MICLEA ${ }^{1}$, Loredana SUCIU ${ }^{1}$, Ionela DOBRIN² ${ }^{2}$ Carmen PUIA ${ }^{1}$ \\ 1) University of Agricultural Sciences and Veterinary Medicine Cluj- Napoca, Romania, \\ 2) University of Agricultural Sciences and Veterinary Medicine Bucuresti, Romania \\ * corresponding author: carmen.puia@yahoo.com
}

Bulletin USAMV series Agriculture 72(1)/2015

Print ISSN 1843-5246; Electronic ISSN 1843-5386

DOI 10.15835/buasvmcn-agr: 11163

\begin{abstract}
In our experiments we have identified and isolated the pathogen Botrytis cinerea Pers. from geranium plants, we have inoculated it on three types of culture media (PDA, Czapek -agar, MA) and studied its morphological and cultural characteristics. The results obtained consist in differences in the morphology, number and distribution of the sclerotia and the dimensions of the conidia. The isolates taken under study showed a great phenotypic diversity influenced by the host plant and by the culture medium where they was grown.
\end{abstract}

Keywords: biology, Botrytis, geranium, gray rot.

\section{INTRODUCTION}

Botrytis cinerea Pers. is an economically important plant pathogen that can attack more than 200 species in the field, greenhouses and storage. This fungus causes gray rot on soft fruits and also blight on flowers and it can be identified by the typical dense gray mold that appears on the decayed area. Symptoms of Botrytis vary greatly depending on the host and the attacked plant organ (Fukumori et al., 2004). The pathogen has a very high phenotypic and genetic variability and adaptability. Morphological features together with DNA analysis are useful for the classification Botrytis species and isolates and also to ensure a better understanding of the genus diversity (Valiunskaite Alma et al., 2010).

\section{AIMS AND OBJECTIVES}

The main purpose of the paper was to study the morphological characteristics of Botrytis cinerea isolates from different varieties of geranium grown on three culture media.

\section{MATERIALS AND METHODS}

The biological material consisted of seven isolates of Botrytis cinerea Pers taken from the following varieties of geranium: Cambi, Angeleyes Orange, Camdared, Campeye, Rainbow White, Balcon Imperial, Ville de Paris Lila. These isolates were phenotypically characterized. A seven day old colony was used for the inoculation of the fungus on three culture media Potato Dextrose Agar (PDA), Czapek - Agar and Malt - Agar (MA). The experiment was conducted in three replicates. Observations of the growth and development of $B$. cinerea colonies on the culture media were performed daily by measuring the diameter of the colony until they filled the Petri dishes. The surface of the colonies was calculated using the diameter measurements.

\section{RESULTS AND DISCUSSIONS}

Studying the cultural characters of Botrytis cinerea isolates grown on the culture mediaitcan be affirmed that the fungus had a better development on PDA medium but a better sporulation on the Czapek medium (Tab. 1). The size of the conidia varied depending of the culture media and of the isolate and the data showed that the conidia from the culture media had higher values compared with the conidia from the infected plants (Tab. 2). 
Tab. 1. The sporulation percent of the colonies on the $12^{\text {th }}$ day

\begin{tabular}{cccccccc}
\hline \multirow{2}{*}{$\begin{array}{c}\text { The culture } \\
\text { media }\end{array}$} & Cambi & $\begin{array}{c}\text { Angeleyes } \\
\text { Orange }\end{array}$ & Camdared & Campeye & $\begin{array}{c}\text { Rainbow } \\
\text { White }\end{array}$ & \multicolumn{2}{c}{ Balcon } \\
\cline { 2 - 8 } Imperial & Lille de Paris \\
\hline PDA & 100.00 & 20.83 & 100.00 & 67.92 & 100.00 & 26.25 & 70.00 \\
\hline Czapek - Agar & 100.00 & 86.25 & 100.00 & 8.33 & 100.00 & 92.92 & 100.00 \\
\hline MA & 87.5 & 100.00 & 100.00 & 69.17 & 66.67 & 80.83 & 67.08 \\
\hline
\end{tabular}

Tab. 2. The dimensions of the Botrytis cinerea Pers. conidia $(\mu \mathrm{m})$

\begin{tabular}{ccccccccc}
\hline \multirow{2}{*}{ Isolate } & \multicolumn{2}{c}{ From plants } & \multicolumn{2}{c}{ PDA } & \multicolumn{3}{c}{ Czapek-agar } & \multicolumn{2}{c}{ MA } \\
\cline { 2 - 9 } & \multicolumn{2}{c}{ Lenght } & Width Lenght & Width & Lenght & Width & Lenght & Width \\
\hline Cambi & 10.66 & 8.60 & 13.39 & 11.20 & 15.10 & 11.31 & 13.11 & 10.09 \\
\hline Angeleyes Orange & 11.39 & 9.23 & 13.94 & 9.71 & 12.91 & 10.65 & 12.62 & 10.12 \\
\hline Camdared & 11.57 & 8.32 & 12.96 & 10.49 & 12.45 & 11.25 & 13.25 & 10.87 \\
\hline Campeye & 11.27 & 8.06 & 16.35 & 10.61 & 12.75 & 10.5 & 12.28 & 10.75 \\
\hline Rainbow White & 11.26 & 8.74 & 12.47 & 9.31 & 11.88 & 10.88 & 13.40 & 11.46 \\
\hline Balcon Imperial & 12.26 & 8.21 & 12.86 & 10.32 & 12.56 & 10.36 & 12.44 & 10.63 \\
\hline Ville de Paris Lila & 10.95 & 7.85 & 13.29 & 11.33 & 12.90 & 10.80 & 11.11 & 10.04 \\
*average of 100 measurements & & & & & & &
\end{tabular}
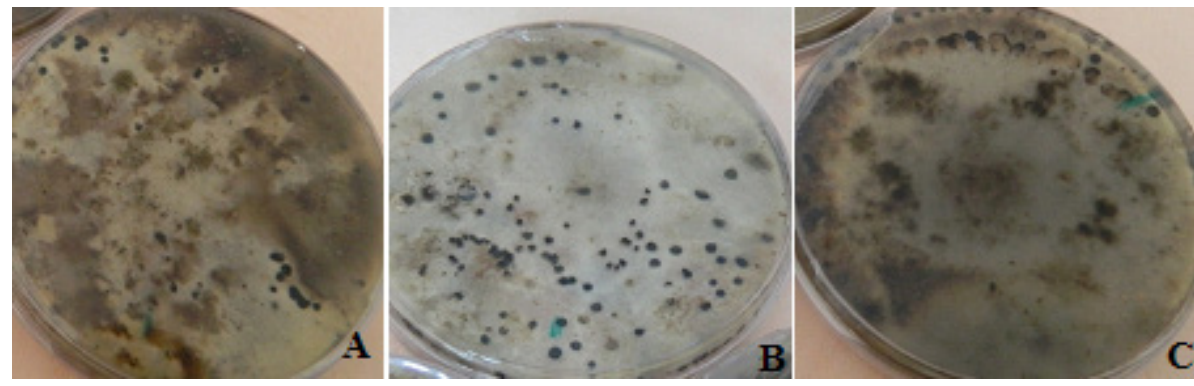

Fig. 1. Sclerotia formed on PDA

(A - Rainbow White, B - Balcon imperial, C - Ville de Paris Lila)

The number of the isolates that recorded a maximum sporulation percent $(100 \%)$ were three on PDA medium (Cambi, Camdared and Rainbow White), four on Czapek - Agar medium (Cambi, Camdared, Rainbow White and Ville de Paris Lila and two varieties on MA medium (Angeleyes Orange and Camdared).

The sclerotia were variables in size, shape, number and distribution; they were rare or abundant with different distribution patterns (Fig. 1).

After 12 days from the inoculation not all the isolates formed the resistant bodies; thereby formed sclerotia three isolates on PDA medium, only one isolate on MA medium and on Czapekagar none of the isolates formed sclerotia. The last situation (on Czapek-Agar medium) it can be related to the low rate of growth of the colonies and also to the high percentage of sporulation at that period after the inoculation.

\section{CONCLUSION}

In this study we found a great phenotypic diversity of the Botrytis cinerea isolates, diversity influenced by the host plant and by the culture medium where they were grown.

\section{REFERENCES}

1. Fukumori Y, Nakajima M, Akutsu K (2004). Microconidia act the role as spermatia in the sexual reproduction of Botrytis cinerea. J. Gen. Plant. Pathol. 70:256-260.

2. Valiunskaite A, Surviliene E, Baniulis D (2010). Genetic diversity and pathogenicity traits of Botrytis spp. isolated from horticultural hosts. Agriculture 97:4. 